\title{
On the Trail of Pulmonary Tuberculosis Based on Rib Lesions: Results From the Human Identified Skeletal Collection From the Museu Bocage (Lisbon, Portugal)
}

\author{
Vítor Matos* and Ana Luísa Santos \\ Departamento de Antropologia, Universidade de Coimbra, 3000-056 Coimbra, Portugal
}

\begin{abstract}
KEY WORDS respiratory diseases; rib periostitis; woven/lamellar bone; early 20th century
\end{abstract}
\begin{abstract}
In the last 20 years, studies on human identified skeletal collections have revealed a significant relationship between new bone formation on the visceral surface of ribs and pulmonary tuberculosis (TB). To improve methods of differential diagnosis of respiratory diseases in archaeological skeletons, an investigation was conducted on 197 individuals from the Human Identified Skeletal Collection of the Museu Bocage (Lisbon, Portugal). This sample included 109 males and 88 females who lived during the 19th-20th centuries, with ages at death ranging from 13-88 years. The skeletons were grouped according to cause of death: 1$)$ pulmonary $\mathrm{TB}(\mathrm{N}=84) ; 2)$ pulmonary non-TB diseases $(\mathrm{N}=49)$; and 3 ) a control group $(\mathrm{N}=64)$ composed of individuals randomly selected among the extrapulmonary non-TB causes of death. The ribs, sterna, scapulae, and clavicles were macroscopically
\end{abstract}

In human populations, tuberculosis (TB) may appear as a chronic or acute infection of any bone or soft tissue (Dunlap et al., 2000). In 1993, the World Health Organization (1994) declared TB to be a "global emergency," and since that time, the prevalence of this contagious disease has increased, especially in developing countries, abetted by HIV infection and the appearance of multidrug-resistant strains (Pozniak, 2001). The World Health Organization (2004a) reported that every second a person is newly infected with the TB bacillus (a mycobacterial pathogen of the Mycobacterium tuberculosis complex), and that one third of the world's population is presently infected. Moreover, in 2002, four million cases of tuberculosis (all forms) were reported, causing approximately two million deaths (World Health Organization, 2004b). The current understanding of the epidemiology of tuberculosis can benefit from documenting the spread of TB worldwide in space and time (Roberts and Buikstra, 2003).

Pulmonary tuberculosis is the most common form of the disease in modern times (Dunlap et al., 2000) as well as in the past in Portugal (Carvalho, 1905, 1907; Castanheira, 1919; Barrosa, 1925; Carvalho, 1948; Videira, 1991; Almeida, 1995; Antunes, 1995) and elsewhere (Johnston, 1993; Daniel, 1997; Roberts and Buikstra, 2003). When paleopathologists study skeletal samples, they do not have access to lung tissue, and therefore for many years the identification of TB relied mainly on tubercular lesions of the spine, or Pott's disease (Aufderheide and Rodríguez-Martín, 1998; Ortner, 2003). Analysis of antero-posterior chest radiographs by Eyler et al. (1996) revealed that rib enlargement was a common finding in living patients suffering from chronic pleural disease, especially TB, and Guttentag and Salwen (1999) noted the presence of new bone forma- observed. New bone formation on the visceral surface of ribs was recorded in $90.5 \%(76 / 84)$ of individuals who died from pulmonary $\mathrm{TB}$, in $36.7 \%$ (18/49) with a pulmonary non-TB disease as cause of death, and in $25.0 \%(16 / 64)$ of the control group. These differences were statistically significant $(P<0.001)$. Furthermore, in individuals with pulmonary TB, the bony lesions presented mainly as lamellar bone on the vertebral end of the upper and middle thoracic rib cage. Proliferative alterations also occurred on one sternum and in nine clavicles and eight scapulae. This work strongly supports the results of similar studies performed on other documented collections, suggesting that new bone formation on ribs, although not pathognomonic, is a useful criterion for the differential diagnosis of pulmonary TB. Am J Phys Anthropol 130:190-200, 2006.

๑2005 Wiley-Liss, Inc.

tion on ribs in the early phases of chronic infections such as TB. In current medical practice, however, rib lesions are not routinely considered because they are not necessary for diagnosis of the disease. As Roberts et al. (1998) argued, modern clinical diagnostic criteria are not always the most suitable for paleopathological studies. This seems to be the case with diagnosis of pulmonary TB. Moreover, as Byers and Roberts (2003, p. 1) stated, "little attention is given to methods for resolving problems in differential diagnosis."

During autopsies, ribs are rarely examined for lesions, even when pleural adhesions are present (Santos and Roberts, in press), although Pinheiro et al. (2004, p. 137) demonstrated that forensic anthropological contexts may provide good opportunities for developing new diagnostic criteria for "unidentified skeletal pathological conditions."

Documented collections of human skeletons are also an excellent resource for paleopathological research (Tobias, 1991). In the last few decades, skeletal diagnosis of pulmonary TB was examined using individuals with known biographical data such as cause of death, age, and sex. Macroscopic observation revealed that new bone formation on the visceral surface of the ribs occurs more frequently in pulmonary TB than in other pulmonary dis-

*Correspondence to: Vítor Matos, Departamento de Antropologia, Universidade de Coimbra, 3000-056 Coimbra, Portugal.

E-mail: vmatos@ci.uc.pt

Received 11 January 2005; accepted 8 March 2005.

DOI 10.1002/ajpa.20309

Published online 19 December 2005 in Wiley InterScience (www.interscience.wiley.com). 
TABLE 1. Distribution of individuals by age class, sex, and cause of death ${ }^{1}$

\begin{tabular}{|c|c|c|c|c|c|c|c|c|}
\hline \multirow[b]{2}{*}{ Group of cause of death } & \multirow[b]{2}{*}{ Sex } & \multicolumn{6}{|c|}{ Age classes (years) } & \multirow[b]{2}{*}{ Total } \\
\hline & & $12-21$ & $22-30$ & $31-40$ & $41-50$ & $51-60$ & $61-88$ & \\
\hline \multirow[t]{3}{*}{ 1. Pulmonary TB } & $\mathrm{M}$ & 12 & 9 & 6 & 10 & 4 & 8 & 49 \\
\hline & $\mathrm{F}$ & 12 & 9 & 4 & 5 & 2 & 3 & 35 \\
\hline & Total & 24 & 18 & 10 & 15 & 6 & 11 & 84 \\
\hline \multirow[t]{3}{*}{ 2. Pulmonary non-TB } & $\mathrm{M}$ & 2 & 1 & 1 & 5 & 3 & 8 & 20 \\
\hline & $\mathrm{F}$ & 0 & 0 & 0 & 1 & 2 & 26 & 29 \\
\hline & Total & 2 & 1 & 1 & 6 & 5 & 34 & 49 \\
\hline \multirow[t]{3}{*}{ 3. Extrapulmonary non-TB } & M & 4 & 6 & 8 & 10 & 4 & 8 & 40 \\
\hline & $\mathrm{F}$ & 4 & 6 & 4 & 5 & 1 & 4 & 24 \\
\hline & Total & 8 & 12 & 12 & 15 & 5 & 12 & 64 \\
\hline Overall total & & 34 & 31 & 23 & 36 & 16 & 57 & 197 \\
\hline
\end{tabular}

${ }^{1} \mathrm{M}$, male; F, female.

eases (Kelley and Micozzi, 1984; Roberts et al., 1994; Santos, 2000), making these lesions very useful in the identification of TB in past populations.

Kelley and Micozzi (1984) studied the Hamann-Todd Collection from the Cleveland Natural History Museum (Cleveland, $\mathrm{OH}$ ), and found that $8.8 \%$ (39/445) of individuals who died from TB showed periostitis on the visceral surface of the ribs. In the Terry Collection at the Smithsonian Institution (Washington, DC), Roberts et al. (1994) found a higher prevalence: $61.6 \%$ (157/255) of individuals who died from pulmonary TB showed this type of lesion. This trend was surpassed in the Identified Skeletal Collection from the Museu Antropológico of the University of Coimbra (Coimbra, Portugal), where $90.9 \%$ (10/11) of juveniles (Santos and Roberts, 2001) and $85.7 \%$ (54/63) of adults with pulmonary TB listed as the cause of death presented rib lesions (Santos and Roberts, in press). It seems evident that "the type of bone formed and its location may allow a differential diagnosis" between pulmonary TB, peritonitis, neoplastic or pulmonary (non-TB) diseases (Santos and Roberts, in press).

The main purpose of this study is to extend the work of previous authors on the development of diagnostic criteria for pulmonary TB based on human skeletons, and to improve the identification of this disease in past times.

Our more specific aims are:

- To quantify and characterize macroscopically the new bone formation present on ribs, sterna, scapulae, and clavicles of individuals from the Human Identified Skeletal Collection from the Museu Bocage (Lisbon, Portugal);

- To compare the frequency and distribution of rib lesions in individuals with pulmonary TB and other causes of death recorded;

- To compare the results obtained in the current work with those from studies done on other identified skeletal collections;

- To discuss new bone formation etiology; and

- To contribute to the definition of diagnostic criteria that can be used to distinguish between pulmonary diseases, applicable to skeletons in archaeological and forensic contexts.

\section{MATERIALS AND METHODS}

The Human Identified Skeletal Collection curated by the Museu Bocage (National Natural History Museum) in Lisbon, Portugal, commonly known as "Lisbon Collection" or "Luís Lopes Collection," was collected between 19811991 by Luís Lopes and Maria Cristina Neto (Cardoso, 2000), and later by Hugo Cardoso (Cardoso, in press). This osteological collection comprises 1,767 human skeletons, both adults and juveniles, recovered from three cemeteries in Lisbon: Alto de São João, Benfica, and Prazeres. The dates of death for these individuals range from the late 19 th century to the $1980 \mathrm{~s}$ (Cardoso, in press).

For 699 individuals, the documentation includes biographical parameters such as name, sex, age at death, birthplace, occupation, and address, as well as cause of death. This information was copied from each cemetery record book and also, when necessary, from civil registrations records (Cardoso, in press). The causes of death are quite reliable because in Portugal, since November 16, 1899 (per Article 14), police authorities were required to send all cadavers with an unknown cause of death (or if there was suspicion of murder) to forensic services for definitive diagnosis of cause of death (Brites, 1912). Moreover, there is good evidence to indicate that medical knowledge, as related to tuberculosis diagnosis in Lisbon in the early 20th century, was relatively up-to-date (Carvalho, 1948). Doubts about the credibility of cause of death do persist, though, because in the past many individuals died without medical assistance. In a few cases, additional information, such as the hospital where the body came from, is also available.

The causes of death recorded for these individuals were coded following the World Health Organization classification (Organização Mundial de Saúde, 1989) in order to define the sample to be studied.

Individuals were clustered into three main groups according to cause of death, sex, and age classes (Table 1). The skeletons with unobservable bones due to factors such as fragmentation, bad preservation, and presence of soft tissues were excluded during sample selection. Group 1 includes the 84 individuals who died from pulmonary TB. The second group is comprised of the 49 skeletons with a pulmonary non-TB cause of death, with pneumonia and bronchitis being the most common conditions. For group 3 , the control group, 64 individuals with extrapulmonary non-TB causes of death were randomly selected and matched to the demographic profile of the 84 cases in group 1.

The total sample was composed of 197 skeletons (109 males and 88 females), with age at death ranging from 13-88 years. These individuals were born between 18191941 and died between 1881-1959 (Matos, 2003). Twentysix $(13.2 \%, 26 / 197)$ individuals were autopsied, three of whom came from the Institute of Legal Medicine and two from Lisbon hospitals. Moreover, for 17 individuals (18.6\%), the hospital where the body came from is recorded, with two of them presenting autopsy signs on the skeleton. There is good evidence to indicate that 
TABLE 2. Macroscopically distinctive features of woven and lamellar bone ${ }^{1}$

\begin{tabular}{clc}
\hline Characteristics & \multicolumn{1}{c}{ Woven bone } & Lamellar bone \\
\hline General & & Heterogeneous unstructured appearance. \\
\hline Surface & Thin, scalloped, and irregular. & $\begin{array}{c}\text { Homogeneous structured appearance. } \\
\text { Thick, compact, and dense. }\end{array}$ \\
\hline \multicolumn{1}{c}{ Porosity } & $\begin{array}{l}\text { Intense porosity, with pores } \\
\text { usually small in diameter. } \\
\text { Many sinuous vascular grooves and channels. }\end{array}$ & $\begin{array}{c}\text { Sparse or nonexistent porosity. } \\
\text { Pores usually large in } \\
\text { diameter and scattered. }\end{array}$ \\
\hline $\begin{array}{l}\text { Limits and cortical } \\
\text { integration }\end{array}$ & $\begin{array}{l}\text { Limits well-defined. } \\
\text { Irregular margins. }\end{array}$ & $\begin{array}{c}\text { Regular limits but difficult to } \\
\text { differentiate from original } \\
\text { cortex of rib. }\end{array}$ \\
& $\begin{array}{l}\text { Cortical integration nonexistent. } \\
\text { Detachable appearance. }\end{array}$ & High cortical integration. \\
\hline Remodeling & $\begin{array}{l}\text { Few signs of remodeling. } \\
\text { No particular arrangement of } \\
\text { fibrous components. }\end{array}$ & $\begin{array}{c}\text { Remodeling evident. } \\
\text { Fibrous structures parallel } \\
\text { oriented to antero-posterior } \\
\text { axis of rib. }\end{array}$ \\
\hline
\end{tabular}

${ }^{1}$ Compiled from descriptions based on radiological analysis (Resnick, 1996a; Guttentag and Salwen, 1999; Helms, 1999), microscopic (Wakely et al., 1991; Schultz, 2001; Ortner and Turner-Walker, 2003), molecular and structural (Gorski, 1998; Weiner et al., 1999; Currey, 2003; Su et al., 2003), and archaeological bone samples studies (Molto, 1990; Pfeiffer, 1991; Lewis et al., 1995; Campillo, 2001; Lambert, 2002).

knowledge of tuberculosis diagnosis in Lisbon in the early 20 th century was relatively up-to-date (Carvalho, 1948).

The bones from the thoracic cage, i.e., the ribs (both external and visceral surfaces), sterna, scapulae, and clavicles, were macroscopically examined by the first author (V.M.) without prior knowledge of cause of death, and in cases of a questionable nature, the second author was consulted.

The identification of individual ribs (siding and seriation) followed standard published criteria (Aiello and Dean, 1990; Dudar, 1993; Mann, 1993; Bass, 1997; Hoppa and Saunders, 1998; White, 2000). To record the exact location of bony lesions on the ribs, three anatomical regions were observed: vertebral end, shaft, and sternal extremity, following the methodology previously described (Santos, 2000; Santos and Roberts, in press). A lamp was always positioned close to the rib surfaces, allowing identification of subtle alterations. In addition, a hand lens $(10 \times)$ was used to aid in visual inspection.

Bone changes were recorded according to their osteolytic or osteoblastic nature (Buikstra and Ubelaker, 1994; Thillaud, 1994; Junqueira and Carneiro, 1999; Schultz, 2001). Two forms of new bone formation, also known as "periosteal reaction," "periostitis," or "periostosis," were distinguished: woven/fibrous and lamellar. The distinction between these variants is not a simple task, and to assist with macroscopic identification, their characteristics were compiled into Table 2. Rib enlargement (Eyler et al., 1996) and "hair-on-end" bone pattern (Yoshikawa et al., 1994; Resnick, 1996b), both defined from radiological criteria, were also sought during macroscopic assessment. When necessary, radiographic analyses were performed in Coimbra University Hospitals. All data analyses were performed using SPSS (2001).

\section{RESULTS}

From the 197 individuals of the sample, 4,276 ribs were observed, which represents $90.4 \%$ of the number expected, assuming 12 pairs of ribs for each individual. An average of 21.7 ribs was observed for each individual, with the twelfth pair the most frequently absent (52.8\% and $54.8 \%$

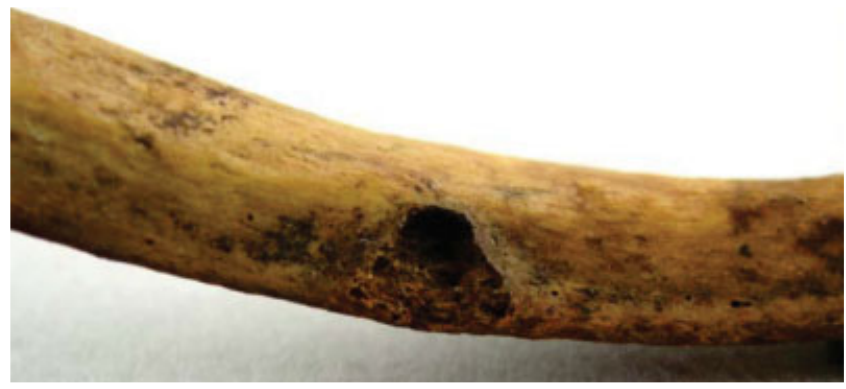

Fig. 1. Osteolytic lesion $(9 \times 7 \mathrm{~mm})$ in costal groove on visceral surface of shaft of fourth right rib (sk. 440, male, 50 years old; cause of death: acute pulmonary edema). Medial/inferior view. [Color figure can be viewed in the online issue, which is available at www.interscience.wiley.com.]

for left and right, respectively). When anatomical regions of the ribs were considered, the sternal end was least often represented, particularly in middle thoracic ribs. The sternum was present in 181 individuals (91.9\%), and 381 clavicles were observed: 191 right $(97.0 \%)$ and 190 left (96.4\%). The right scapulae were present for all 197 individuals, and only two left scapulae were missing.

\section{Osteolytic lesions}

A low frequency of osteolytic lesions was found on ribs, with only 9 of 197 individuals affected (4.6\%). Seventeen of the 4,276 ribs $(0.4 \%)$ showed at least one erosive focus (Fig. 1). These lesions were randomly distributed when thoracic cage side or rib numbers were considered (Table 3). However, the shaft and the visceral surface of ribs were the most common locations. Slight differences were found between disease groups when affected individuals were considered. In group 1 (pulmonary TB), three cases presented lesions, and three ribs were affected in one skeleton. One destructive focus was found in a group 2 individual (skeleton (sk.) 440), with "pulmonary edema" listed as cause of death. In group 3 , five individuals were affected, with a total of 10 ribs involved. 
TABLE 3. Distribution and size of osteolytic lesions on ribs, by cause of death

\begin{tabular}{|c|c|c|c|c|c|c|}
\hline \multirow[b]{2}{*}{ Skeleton number } & \multirow[b]{2}{*}{ Cause of death } & \multicolumn{4}{|c|}{ Rib } & \multirow[b]{2}{*}{ Dimension $(\mathrm{mm})$} \\
\hline & & Number & Side & Region & Surface & \\
\hline \multirow[t]{3}{*}{27} & Pulmonary TB & 3 & Left & Shaft & Visceral & $7 \times 6$ \\
\hline & & 8 & Right & Shaft & $\begin{array}{l}\text { Visceral } \\
\text { External }\end{array}$ & \\
\hline & & 9 & Right & Shaft & Visceral & \\
\hline 470 & Pulmonary TB & $0^{1}$ & Right & Shaft & & \\
\hline 1,139 & Pulmonary TB & 7 & Left & Shaft & Visceral & $15 \times 3$ \\
\hline 440 & Pulmonary edema & 4 & Right & Shaft & Visceral & $9 \times 7$ \\
\hline 30 & Uterus cancer & 5 & Left & Vertebral & Visceral & $4 \times 2$ \\
\hline 53 & Heart failure & 4 & Left & Shaft & Visceral & \\
\hline \multirow[t]{2}{*}{181} & Spinal injury & 2 & Left & Shaft & Visceral & $7 \times 4$ \\
\hline & & 3 & Left & Shaft & Visceral & \\
\hline \multirow[t]{3}{*}{324} & Renal sclerosis & 4 & Left & Shaft & Visceral & $10 \times 4$ \\
\hline & & 7 & Left & Shaft & Visceral & \\
\hline & & 5 & Right & Vertebral & Visceral & \\
\hline \multirow{4}{*}{1,106} & Breast cancer & 10 & Left & Shaft & Visceral & $13 \times 7$ \\
\hline & & 3 & Right & Sternal & Visceral & $2 \times 2$ \\
\hline & & 10 & Right & Shaft & Visceral & $28 \times 9$ \\
\hline & & & & & External & $24 \times 7$ \\
\hline
\end{tabular}

1 Two unidentified rib fragments.

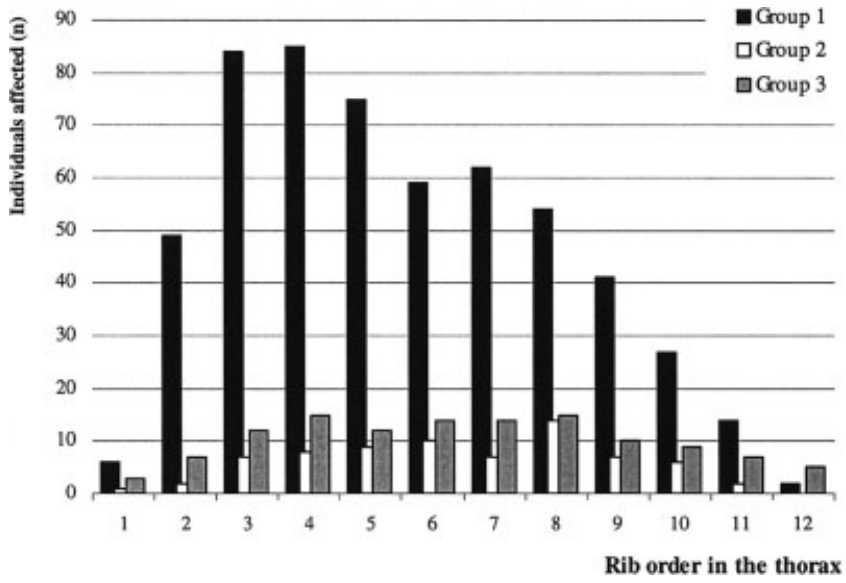

Fig. 2. Distribution of new bone formation by rib number and cause of death.

In the remaining bones studied, the sternum did not present any osteolytic lesions, one clavicle was affected in an individual from group 1 (sk. 313) with a right-sided solitary erosive focus, and scapulae were affected in two cases, both with concomitant destructive lesions on the ribs (Table 3). Skeleton number 440 (group 2), whose recorded cause of death was "pulmonary edema," had a destructive lesion on the left scapula, near the subscapular fossa $(10 \times 10 \mathrm{~mm}$ in size $)$, and in the fourth right rib. In individual 324 (group 3), who died from "renal sclerosis," lytic lesions ca. $7 \times 10 \mathrm{~mm}$ existed in both scapulae, and three ribs were also affected.

\section{Proliferative lesions}

Proliferative lesions on the ribs were observed in 110 of 197 individuals studied (55.8\%). New bone formation (Fig. 2) was present on the visceral surface of $757(17.7 \%)$ out of 4,276 ribs observed, and its presence in the external surface of ribs only occurred in association with traumatic lesions.

Ribs affected. When cause of death was considered (Table 4), individuals who died from pulmonary TB (group
1) presented a higher prevalence $(90.5 \%)$ of new bone formation when compared with groups $2(36.7 \%)$ and 3 $(25.0 \%)$. Chi-square comparison of the rates revealed a highly significant difference $\left(\chi^{2}=72.804,2 \mathrm{df}, P=0.000\right)$. However, differences between groups 2 and 3 proved not to be significant ( $\chi^{2}=1.817,1 \mathrm{df}, P=0.178$ ).

The analysis of new bone formation distribution in the thoracic cage revealed that bilateral lesions were much more frequent in group 1 (Table 4). The rates for bilateral and unilateral lesions were significantly different within group $1\left(\chi^{2}=23.395,2 \mathrm{df}, P=0.000\right)$, but not within groups $2\left(\chi^{2}=0.000,2 \mathrm{df}, P=1.000\right)$ or $3\left(\chi^{2}=0.875,2 \mathrm{df}\right.$, $P=0.646)$. Interestingly, bilateral lesions were not found on two individuals with "bilateral pulmonary TB" recorded as cause of death: sk. 969 did not present new bone formation on the ribs, and in sk. 367, only the seventh right rib was involved. In the affected individuals from group 2 , six had bilateral lesions and 12 had unilateral lesions, six for each side. The right side of the thoracic cage was slightly more affected than the left side in group 1 , and the inverse occurred in group 3 .

The average number of ribs with lesions by individual was nearly the same in groups 1 and 3 (7.4 and 7.6, respectively), but the first group presented much higher values of rib involvement $(30.7 \%)$ as well as lower standard deviation values (Table 5). When the entire rib cage was considered, the first and twelfth ribs were rarely involved, and ribs 3-7 were the most affected in group 1 (Fig. 2). Moreover, in individuals who died from pulmonary TB, new bone formation on the visceral surface of ribs was frequently observed in adjacent ribs (Fig. 3). Significant differences $\left(\chi^{2}=8.632,2 \mathrm{df}, P=0.013\right)$ between the three groups (group 1: $73.9 \%$, or $68 / 92$; group 2: $12.0 \%$, or $11 / 92$; group $3: 14.1 \%$, or $13 / 92$ ) were found, and extension from the vertebral end to the shaft of ribs was common.

The eighth rib was the most affected in group 2, and in group 3 (the control group), the fourth and eighth ribs were the most affected. Individuals from these groups revealed a more random pattern of ribs affected, and unlike group 1 , lesions were rarely present in adjacent ribs.

The vertebral end of the ribs was the most common location of new bone formation in individuals from groups 1 
TABLE 4. Distribution of individuals affected by new bone formation on ribs by cause of death and lesion laterality ${ }^{1}$

\begin{tabular}{|c|c|c|c|c|c|c|c|c|c|}
\hline \multirow[b]{3}{*}{ Group of cause of death } & \multirow[b]{3}{*}{$\mathrm{N}$} & \multirow{2}{*}{\multicolumn{2}{|c|}{$\begin{array}{l}\text { Individuals } \\
\text { affected }\end{array}$}} & \multicolumn{6}{|c|}{ Laterality of lesions } \\
\hline & & & & \multicolumn{2}{|c|}{ Left } & \multicolumn{2}{|c|}{ Right } & \multicolumn{2}{|c|}{ Bilateral } \\
\hline & & $\mathrm{n}$ & $\%$ & $\mathrm{n}$ & $\%$ & $\mathrm{n}$ & $\%$ & $\bar{n}$ & $\%$ \\
\hline 1 & 84 & 76 & 90.5 & 13 & 17.1 & 18 & 23.7 & 45 & 59.2 \\
\hline 2 & 49 & 18 & 36.7 & 6 & 33.3 & 6 & 33.3 & 6 & 33.3 \\
\hline 3 & 64 & 16 & 25.0 & 5 & 31.3 & 4 & 25.0 & 7 & 43.8 \\
\hline Total & 197 & 110 & 55.8 & 24 & 21.8 & 28 & 25.5 & 58 & 52.7 \\
\hline
\end{tabular}

${ }^{1} \mathrm{~N}$, number of individuals observed; $\mathrm{n}$, number of individuals affected.

TABLE 5. Distribution of proliferative lesions on visceral surface of ribs ${ }^{1}$

\begin{tabular}{|c|c|c|c|c|c|c|c|c|c|c|c|c|c|c|c|}
\hline \multirow[b]{3}{*}{ Group } & \multirow[b]{3}{*}{$\operatorname{Ribs}(\mathrm{N})$} & \multicolumn{5}{|c|}{ Ribs affected } & \multicolumn{9}{|c|}{ Anatomical region of rib } \\
\hline & & \multicolumn{2}{|c|}{ Total } & \multicolumn{3}{|c|}{ By individual } & \multicolumn{3}{|c|}{ Vertebral end } & \multicolumn{3}{|c|}{ Shaft } & \multicolumn{3}{|c|}{ Sternal end } \\
\hline & & $\mathrm{n}$ & $\%$ & Mean & SD & Median & $\mathrm{n}(\mathrm{obs})$ & $\mathrm{n}(\mathrm{les})$ & $\%$ & $\mathrm{n}(\mathrm{obs})$ & $\mathrm{n}(\mathrm{les})$ & $\%$ & n (obs) & n (les) & $\%$ \\
\hline 1 & 1,820 & 558 & 30.7 & 7.4 & 4.4 & 7.0 & 557 & 477 & 85.6 & 555 & 208 & 37.5 & 494 & 159 & 32.2 \\
\hline 2 & 1,020 & 75 & 7.4 & 4.1 & 3.1 & 3.0 & 75 & 39 & 52.0 & 75 & 32 & 42.7 & 69 & 41 & 59.4 \\
\hline 3 & 1,436 & 124 & 8.6 & 7.6 & 6.6 & 5.5 & 123 & 100 & 81.3 & 124 & 67 & 54.0 & 96 & 41 & 42.7 \\
\hline Total & 4,276 & 757 & 17.7 & & & & 755 & 616 & & 754 & 307 & & 659 & 241 & \\
\hline
\end{tabular}

${ }^{1} \mathrm{~N}$, number of ribs observed; $\mathrm{n}$, number of ribs affected; $\mathrm{n}$ (obs), number of ribs observed; $\mathrm{n}$ (les), number of ribs with proliferative lesions; SD, standard deviation.

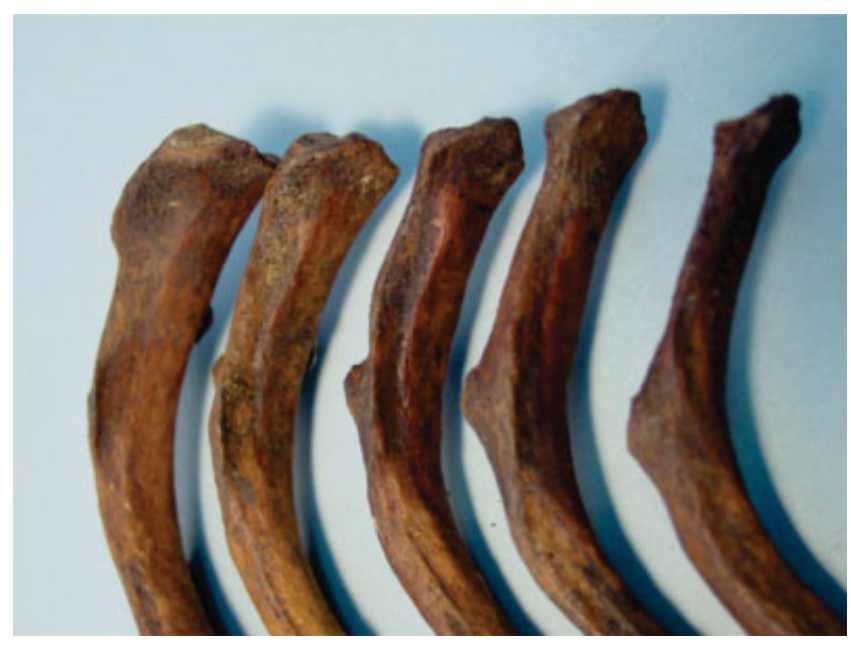

Fig. 3. Lamellar bone on vertebral end of third to seventh right ribs (sk. 1,422, male, 38 years old; cause of death: pulmonary TB). Antero/superior view. [Color figure can be viewed in the online issue, which is available at www.interscience.wiley.com.]

$(85.6 \%)$ and $3(81.3 \%)$ (Table 5$)$. In both groups, the shaft and the sternal extremity presented lower values of involvement. In group 2 , the distribution of rib proliferative lesions was more homogeneous, but the sternal end was slightly more affected when compared with other regions.

Lamellar vs. woven bone on ribs. The lamellar form was the most common type of bony proliferative lesion found among pulmonary TB individuals, particularly on the vertebral end $(59.1 \%$, or $329 / 557)$ of the visceral surface of ribs. In contrast, woven bone was the most common type present on the sternal end of ribs $(53.6 \%$, or $37 / 69)$ of individuals from the pulmonary non-TB group. The concomitant presence of both types of new bone formation, or mixed lesions (Fig. 4), was also observed in the same

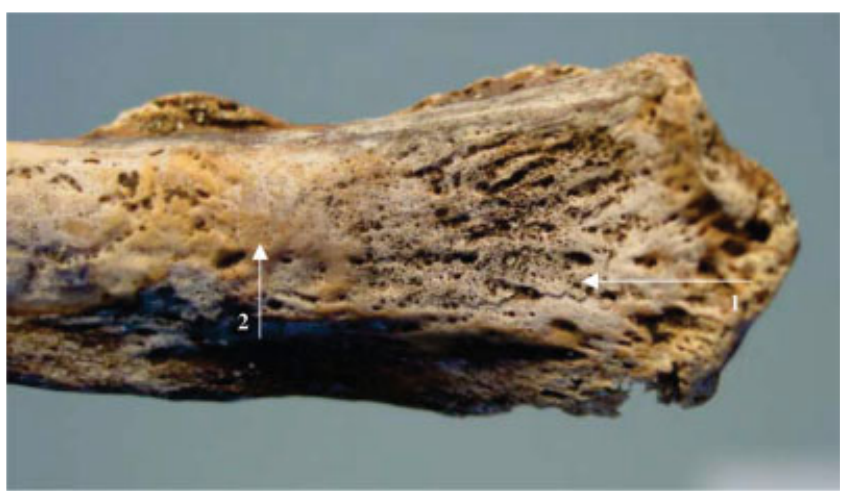

Fig. 4. Woven bone (arrow 1) and lamellar bone (arrow 2) on visceral surface of vertebral end of sixth left rib (sk. 1,547, male, 44 years old; cause of death: pulmonary TB). Anterior view. [Color figure can be viewed in the online issue, which is available at www.interscience.wiley.com.]

region of the ribs. These were frequently observed on the vertebral end of the ribs from individuals in group 1 (pulmonary TB) $(24.4 \%$, or $135 / 557)$ and group $3(15.4 \%$, or $19 /$ $123)$, but they also occurred (15.9\%, or $11 / 69)$ on the sternal end of ribs in individuals who died from a pulmonary non-TB disease.

Sterna, clavicles, and scapulae. New bone formation was detected on both the anterior and posterior surfaces of the sternum (sk. 53) in an individual with "heart failure" listed as cause of death (Table 6). Clavicles and scapulae were not affected by proliferative lesions in group 2, but seven individuals, four from group 3 and three from group 1 (Fig. 5), had at least one of these bones involved.

\section{Other proliferative bone responses}

Rib enlargement. From the 98 ribs recorded as "enlarged" (based on macroscopic examination), 87 
TABLE 6. Individuals affected by proliferative lesions on sternum, clavicles, and scapulae

\begin{tabular}{|c|c|c|}
\hline $\begin{array}{l}\text { Skeleton } \\
\text { number }\end{array}$ & Cause of death & Bones affected \\
\hline 53 & Heart failure & $\begin{array}{l}\text { Clavicles, scapulae, } \\
\text { and sternum }\end{array}$ \\
\hline 191 & Cerebral hemorrhage & Right clavicle \\
\hline 204 & Chronic myocarditis & Clavicles and scapulae \\
\hline 273 & Pulmonary TB & Clavicles \\
\hline 294 & Pulmonary TB & Right scapula \\
\hline 336 & Peritonitis & Clavicles and scapulae \\
\hline 422 & Pulmonary TB & Left scapula \\
\hline
\end{tabular}
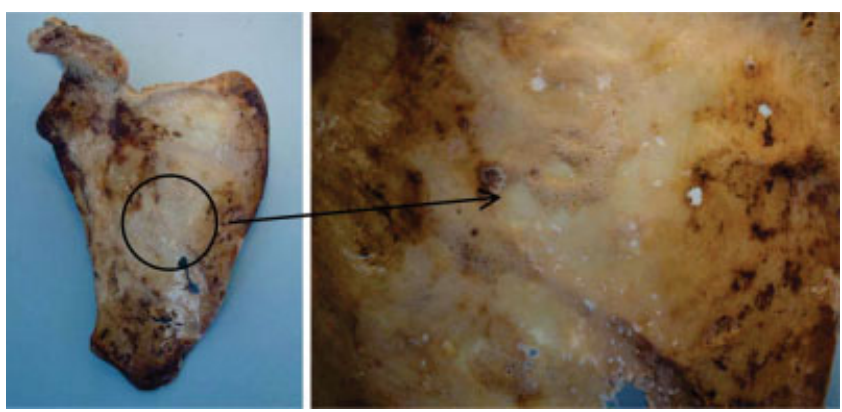

Fig. 5. New bone formation on subscapular fossa of right scapula (sk. 1,291, male, 42 years old; cause of death: pulmonary TB). Anterior view. [Color figure can be viewed in the online issue, which is available at www.interscience.wiley.com.]

$(93.5 \%)$ cases were confirmed by radiographic analysis (Fig. 6). The radiographs showed a layer of remodeled new bone attached to the rib surface that resulted in enlargement of the shaft, visible to the naked eye.

"Hair-on-end" bone pattern. Simultaneously with the woven and/or lamellar variants, this type of bone response was found in two skeletons from the extrapulmonary nonTB group. In an individual who died from "heart failure" (sk. 53), all of the ribs were affected, with small spicules extending perpendicular to the underlying cortex, especially in the costal groove. When observed in radiographs, they corresponded to initial phases of "hair-on-end" or "sunburst" patterns (Yoshikawa et al., 1994; Resnick, 1996b). The presence of generalized macroporosity accompanied by osteolytic focus was also noted. Radiographic analysis of ribs (Fig. 7) revealed focal areas of a destructive nature. The scapulae and clavicles also presented these types of alterations. In sk. 399 (with "carcinoma of the uterus" listed as cause of death), spiculated bone was recorded on the shaft of the fifth to ninth right ribs. This reactive bone type was concomitant with mixed lesions of woven and lamellar bone.

\section{DISCUSSION \\ Osteolytic lesions}

In the current study, 10 individuals presented osteolytic lesions. Group 3, the individuals with an extrapulmonary non-TB cause of death, was the most affected, with five individuals involved. Two (sk. 30 and 1,106) died from "uterus cancer" and "breast cancer," respectively. Thus, the rib lesions may have had a metastatic origin. Rib destructive foci can be present in primary malignant tumors, as reported in the "Lisbon Collection" by Marques and Matos (2002) in 3 out of 4 females with "breast can-
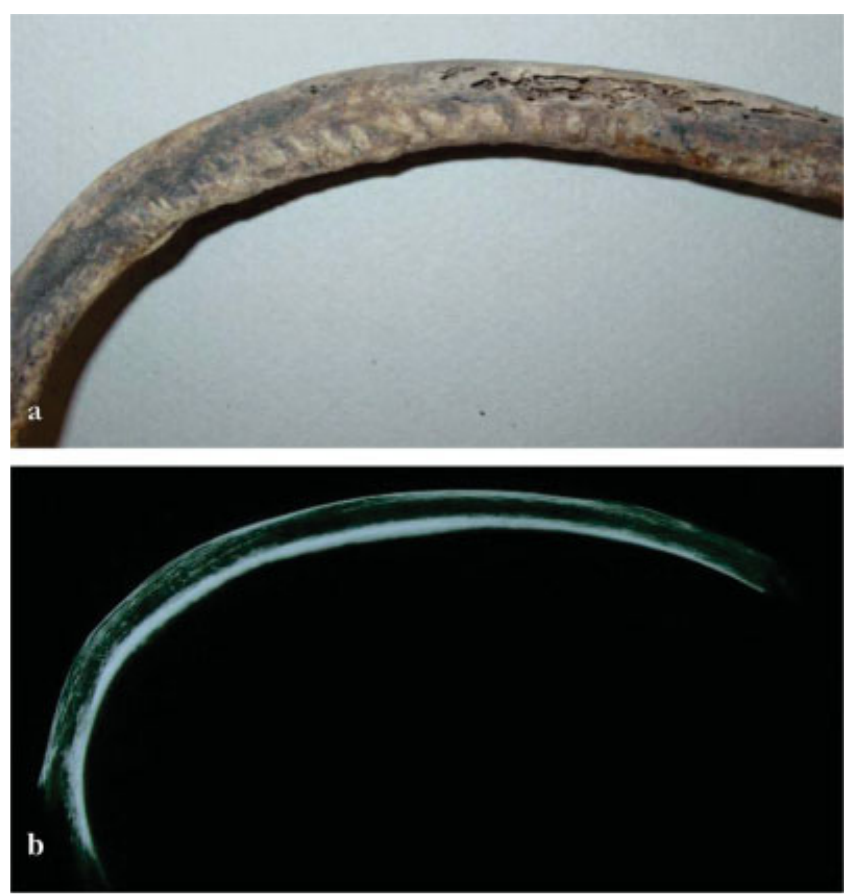

Fig. 6. Enlargement and rough surface appearance of visceral surface of eighth left rib (sk. 332, male, 56 years old; cause of death: pulmonary TB). a: Superior view. b: Radiograph in superior norm (General Electric, Senographe DMR, $28 \mathrm{KV}, 20 \mathrm{mAs}$ ). [Color figure can be viewed in the online issue, which is available at www.interscience.wiley.com.]
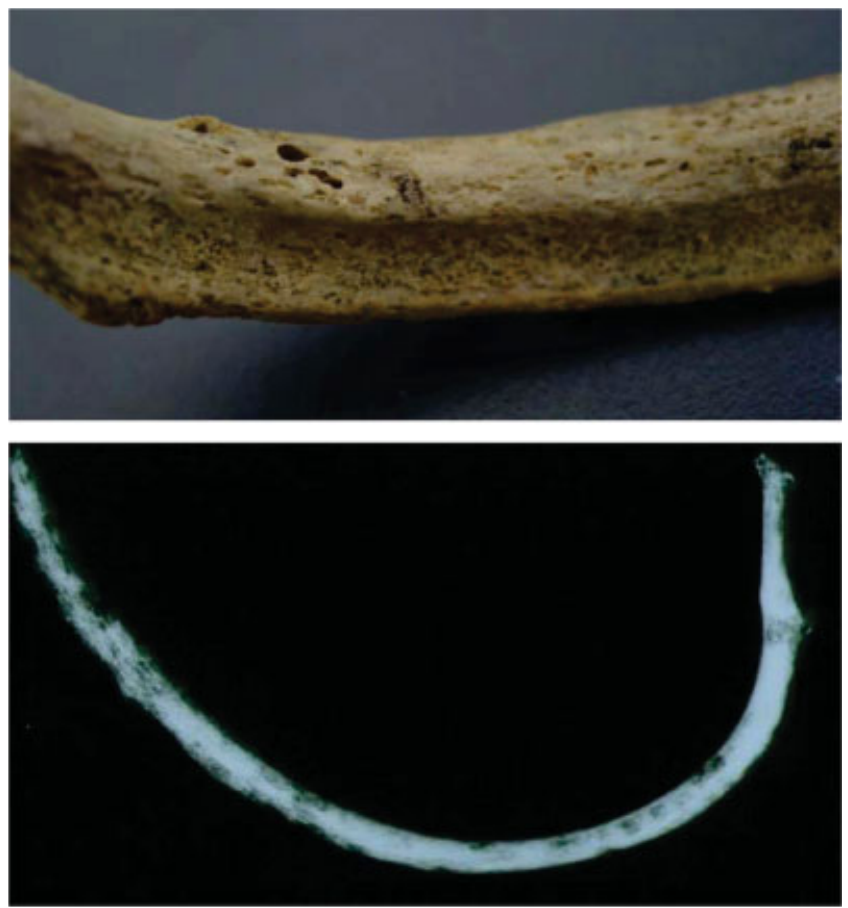

Fig. 7. Fourth left rib of sk. 53 (male, 77 years old; cause of death: heart failure), presenting spiculated bone formation along costal groove and generalized porosity. a: Anterior/inferior view of shaft. b: Radiograph in superior view (General Electric, Senographe DMR, $28 \mathrm{KV}, 20 \mathrm{mAs}$ ). [Color figure can be viewed in the online issue, which is available at www.interscience. wiley.com.] 
cer" as cause of death, and also as observed by Resnick (1996b) in radiographs of cancer patients. The other three individuals from group 3 with osteolytic lesions on the ribs had "heart failure" (sk. 53), "spinal injury" (sk. 181), and "renal sclerosis" (sk. 324), respectively, listed as causes of death. The last individual also presented destructive foci on both scapulae.

Among the individuals who died from pulmonary nonTB diseases (group 2), only sk. 440, with "pulmonary edema" as cause of death, had osteolytic foci on a right rib and on the left scapula. Possible explanations for the appearance of osteolytic lesions in the previous four cases may be that the reported cause of death was not the only disease affecting the individuals, or that the lytic lesions were not associated with the cause of death and thus were not documented. Moreover, the possibility of misdiagnosis cannot be rejected in individuals who died in the first half of the 20th century.

Destructive lesions were found in $4.8 \%$ (4/84) of individuals with pulmonary TB (group 1). Three of these individuals (sk. 27, 470, and 139) were affected in their ribs, and sk. 313 was affected on the right clavicle. The ribs were most commonly affected on the shaft; this location is also preferentially involved in clinical patients with skeletal TB (Leader, 1950; Tatelman and Drouillard, 1953). However, as Lee et al. (1993) stated, the clinical definition of rib tuberculosis is controversial, although some medical evidence was reported (Leader, 1950; Brown, 1980; Ip et al., 1989; Lee et al., 1993; Asnis and Niegowska, 1997; Chang et al., 1998, 1999). There is also disagreement among researchers regarding the frequency of rib involvement on bone tuberculosis, some reporting it as rare (Dunlap et al., 2000; Leader, 1950), with no more than 5\% of cases of skeletal TB being so affected (Tatelman and Drouillard, 1953), while others claim that it accounts for around $15 \%$ of all extrapulmonary TB cases (Mathlouthi et al., 1998). A possible explanation for destructive lesions on ribs is the hematogenous spread of the bacilli, provoking infection in bone (Roberts and Manchester, 1995; Aufderheide and Rodríguez-Martín, 1998), as described in one forensic case with a positive identification of aDNA from Mycobacterium tuberculosis complex (Donoghue et al., 1999; Ubelaker et al., 2000), and also in one individual from the Coimbra Collection (Santos and Roberts, in press). Differential diagnoses for these lesions must include carcinomas, lymphoma, and other infectious diseases (Tatelman and Drouillard, 1953; Aufderheide and Rodríguez-Martín, 1998).

\section{New bone formation on ribs and cause of death}

From the results, we emphasize the existence of an association between the frequency of new bone formation on the visceral surface of ribs and cause of death: $90.5 \%$ (76/84) in pulmonary TB (group 1), 36.7\% (18/49) in pulmonary non-TB cases (group 2), and $25.0 \%$ (16/64) in extrapulmonary non-TB (group 3). In pulmonary TB patients, this type of bone proliferation is frequently bilateral $(59.2 \%)$ and located in the middle thoracic cage (third to seventh ribs, and especially the fourth). Lesions in adjacent ribs are frequent, with seven being the average number of ribs affected in an individual. Moreover, the vertebral end is the region of the rib preferentially involved. These results are very suggestive of rib lesions as a diagnostic tool for identification of pulmonary TB. This pattern of distribution resembles the pattern of affected pulmonary tissues most often observed in the pathogenesis of pulmonary tuberculosis (Cotran et al., 1999), as the vertebral ends of the middle/superior thoracic ribs correspond anatomically to posterior apical segments of the superior pulmonary lobes (Moore, 1995).

Lamellar bone is the variant that often occurs in individuals with pulmonary TB listed as cause of death. It is a more remodeled and organized form of bone (Gorski, 1998) and, in theory, is compatible with a chronic infectious disease such as pulmonary tuberculosis. Historical records from the early 20th century, a period before antibiotics and immunization, reveal that 2.5 years was the average survival time of a non-cured tuberculous patient (Carvalho, 1907), and this time period is compatible with the development of lamellar bone lesions.

Nevertheless, in some circumstances, pulmonary TB progresses rapidly to death (Coutinho, 1957; Cotran et al., 1999). In this case, there is no time for a bony response in the ribs. This situation could account for the eight unaffected individuals of group 1 who, as suggested by Roberts (2002, p. 103), "may have died before TB was registered in osseous tissue" or, alternatively, "the stated cause of death may be incorrect for some individuals, and some people may have been suffering from tuberculosis and/or another pulmonary disease that was not the stated cause of death" (Roberts et al., 1998, p. 57). Individuals 1,418 (group 1) and 336 (group 3) died from "pulmonary and intestinal TB" and "diffuse peritonitis caused by acute appendicitis," respectively, and both presented new bone formation on the middle ribs. This result does not support the preferential inferior thoracic location of new bone formation in peritonitis in the Coimbra Collection (Santos, 2000; Santos and Roberts, in press).

Of the 49 individuals from the group of pulmonary nonTB individuals (group 2), 36.7\% (18/49) had new bone formation on the visceral aspect of the ribs. Unlike the pattern in group 1, the distribution of lesions on the ribs in group 2 showed a more random pattern, and few ribs were affected in each individual. New bone formation was mainly woven in nature and the sternal ends of inferior ribs were affected more frequently, suggesting a different diagnosis from group 1 . Woven bone, a more disorganized type denoting rapid formation (Gorski, 1998; Su et al., $2003)$, is more compatible with acute infectious processes, such as the diseases listed as causes of death in group 2 . However, in $55.0 \%$ (10/18) of individuals affected with new bone formation on the visceral surface of the ribs from group 2 (five with "bronchopneumonia," two with "bronchitis," and "pneumonia," "pulmonary abscess," and "pulmonary bacilosis" for one individual each), the lamellar and/or woven bone was located on the vertebral end, as in group 1 . This pattern raises the possibility that these individuals were suffering from pulmonary TB, yet died from a different acute respiratory infection, or that the cause of death recorded concealed pulmonary TB, a common situation due to social stigma (Carvalho, 1948; Hardy, 1994). Another hypothesis is misdiagnosis, because an accurate TB identification was not always easy, due to shared symptoms with infections such as bronchopneumonia, pneumonia, and chronic bronchitis (Carvalho, 1907; Carvalho, 1948).

Sixteen $(25 \%)$ of the 64 individuals from group $3 \mathrm{had}$ new bone formation on at least one rib. Seven of the 16 $(43.7 \%)$ who died from heart disease (e.g., myocarditis, cardiopathy, and infarct) showed new bone formation. Heart disease, namely tuberculous pericarditis, could be responsible for the rib lesions, as hypothesized in the Coimbra Human Identified Skeletal Collection (Santos, 
DIAGNOSIS OF PULMONARY TB BASED ON RIB LESIONS

TABLE 7. Comparison between distributions of new bone on rib visceral surfaces in studies of identified human skeletal collections

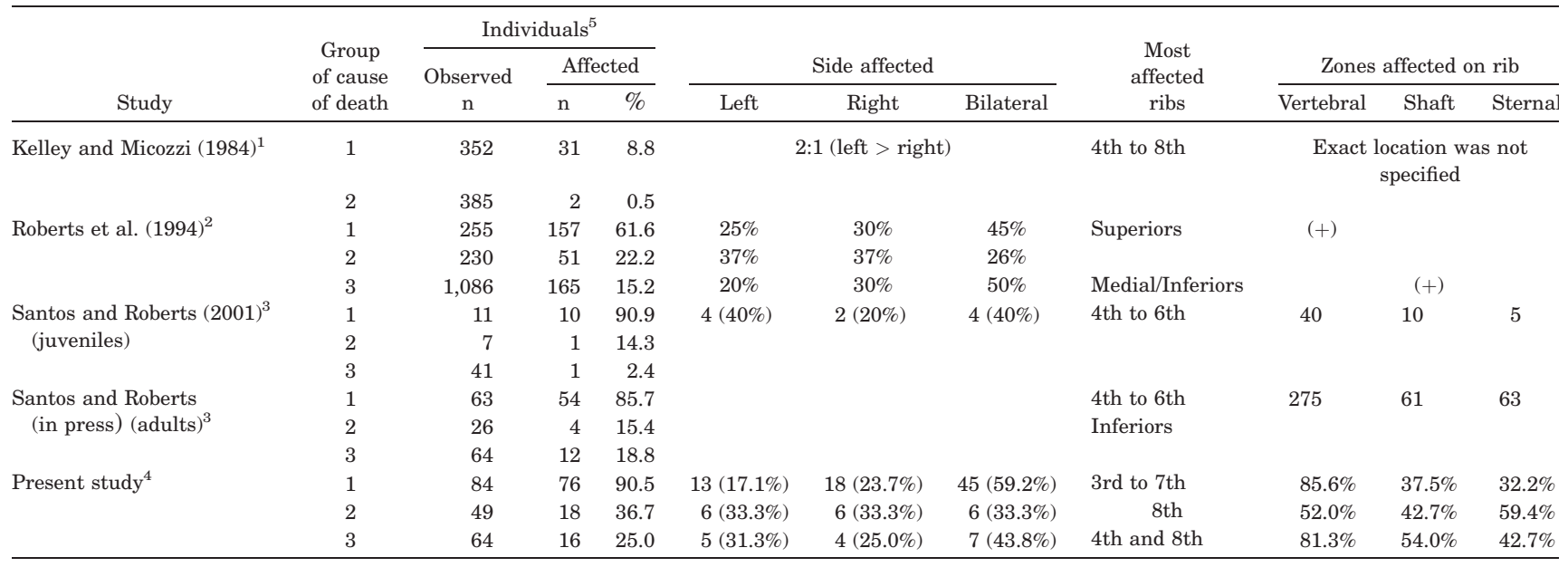

${ }^{1}$ Hamann-Todd Collection (Cleveland Museum of Natural History, Cleveland, $\mathrm{OH}$ ).

${ }^{2}$ Terry Collection (National Museum of Natural History, Smithsonian Institution, Washington, DC).

${ }^{3}$ Coimbra Collection (Museu Antropológico, Universidade de Coimbra, Coimbra, Portugal).

${ }^{4}$ Lisbon Collection (Museu Bocage, Museu Nacional de História Natural, Lisbon, Portugal).

$5 \mathrm{n}$, number of individuals; $(+)$, most frequent.

2000), or these individuals may have been infected with one disease but their deaths attributed to another health problem (Santos and Roberts, 2001). Diagnosis of disease based on skeletons is difficult, since the bony response to disease processes is limited (Wood et al., 1992; Wright and Yoder, 2003), and "different diseases can affect the skeleton in similar ways" (Ortner, 1992, p. 7). In one individual (sk. 53) who died from "heart failure," all ribs, clavicles, and scapulae showed "hair-on-end" bone involvement. Additional research on identified skeletons is needed on this topic.

The "hair-on-end" type of reaction also occurred in sk. 399 , with "carcinoma of the uterus" listed as cause of death. However, it is possible that these cases may represent different diagnoses from the group 1 cases, because the types of new bone formation are completely different. Furthermore, it can be hypothesized that the reactive bone may represent a response to skeletal metastases from the primary malignant neoplasm (Resnick, 1996b). "Hair-on-end" bone, associated with woven/lamellar forms and/or osteolytic lesions on rib shafts, was also found by Marques and Matos (2002) in identified cases of "breast cancer" from the "Lisbon Collection." Nevertheless, in individual 109 who died from "larynx cancer," "hair-onend" bone was not found, but lamellar bone was present on the visceral surface of the shaft and on the sternal end from the third to fifth and eighth right ribs.

Besides heart disease and malignant conditions, other causes of death were represented in individuals from group 3. In sk. 324 (whose recorded cause of death was "renal sclerosis"), the origin of bony alterations on the ribs is dubious due to the concomitant presence of new bone formation (third to tenth left and third to eleventh right ribs) and osteolytic foci (fourth and seventh left and fifth right ribs). It can be questioned whether this individual was suffering from pulmonary and/or renal tuberculosis, with this disease being responsible for those lesions.

The woven bone found in the third to fourth left ribs of sk. 336 is not easily related to the "diffuse peritonitis due to acute appendicitis" registered as cause of death. All the bones observed show generalized porosity on muscular insertion sites, and so another disease could be present.
Skeleton 181 (with "spinal injury" as cause of death) presented bilateral lesions, characterized by irregular and asymmetric lamellar bone on the shafts of the fifth to sixth and eighth left ribs. The same type of bone was observed on the shaft of the second to eighth right ribs of individual 92, who died from "hepatic fibrosis." This individual also presented a solitary focus of woven bone on the shaft of the eighth left rib.

Individual 291 (with "polyserositis" as cause of death) showed woven bone exclusively in the right thoracic cage, extending from the visceral surfaces from ribs 2-12. In an individual (sk. 191) who died from "cerebral hemorrhage," only the visceral surface at the vertebral end of the third rib was affected with woven bone.

In the aforementioned cases, the individuals showed evidence of rib lesions, but a non-tuberculous cause of death was recorded. Similarly, TB might be present in a person, but might not be responsible for the death (Roberts et al., 1994; Roberts, 1999).

\section{Comparison between studies on rib lesions based on individuals with known cause of death}

The present study (Table 7) supports the patterns reported in previous studies of other identified skeletal collections (Kelley and Micozzi, 1984; Roberts et al., 1994; Santos and Roberts, 2001; Santos and Roberts, in press), suggesting that observation of new bone formation on the visceral surface of the ribs is an important new diagnostic tool for the identification of pulmonary TB. In the Coimbra Human Identified Skeleton Collection (Santos, 2000; Santos and Roberts, 2001), similar frequencies of new bone formation in individuals who died from pulmonary TB were observed in juveniles $(90.9 \%)$ and adults $(85.7 \%)$. Slightly lower values were found in the Terry Collection $(61.6 \%)$ by Roberts et al. (1994). Kelly and Miccozi (1984, p. 382) found, in the Hamann-Todd Collection, that $8.8 \%$ (39/445) individuals who died from "tuberculosis infection" had "light to moderate periostitis on the internal aspect of one or more ribs." All these studies found rib lesions to be more common in those listed with pulmonary TB as cause of death. 
The spread of TB in human populations depends on a complex range of factors such as virulence of the bacteria, host resistance (Ortner, 2003), malnutrition, and living conditions (Aufderheide and Rodríguez-Martín, 1998; Roberts and Buikstra, 2003). Many cases of TB were misdiagnosed in the past; therefore, the records of TB, even after Robert Koch's bacillus discovery, should be considered with caution (Santos, 1999).

\section{Etiology of new bone formation on ribs}

A hypothetical explanation for the origin of new bone formation on ribs is that it represents an inflammatory response to direct contact with a pulmonary infectious focus or pleurisy (Roberts et al., 1994; Roberts et al., 1998; Santos and Roberts, 2001; Santos and Roberts, in press). Another possibility considers the close association between the vertebral end of the ribs and the posterior intercostal lymph nodes. These glands near the vertebral end of the ribs become continuously inflamed during pulmonary TB, and ruptures can occur (Harisinghani et al., 2000 ), with possible stimulation of new bone formation in adjacent bones. Buckley and Dias (2002) proposed a similar mechanism for the etiology of tibial periostitis in treponematosis. These two hypotheses are not mutually exclusive. Moreover, for differential diagnosis, sarcoidosis, lymphomas, tumors, fungal infections, and brucellosis (Nyman et al., 1996) must also be considered. Further investigation is needed on this topic.

\section{CONCLUSIONS}

This research was conducted on the Human Identified Skeletal Collection from Museu Bocage, which represents a Portuguese population from the late 19th-early 20th centuries. Demographic information and cause of death are available for these individuals. As in other studies performed on identified collections (Kelley and Micozzi, 1984; Roberts et al., 1994; Santos and Roberts, 2001), the current research suggests that new bone formation on the visceral surface of the ribs is more frequent in individuals who died from pulmonary TB. The frequencies observed may be underestimated because the new bone is fragile and often easily detached if cortical integration is not complete. Key characteristics, such as the nature (osteolytic or proliferative; lamellar or woven) and location of the lesions on the thoracic cage, although not pathognomonic, may enable a differential diagnosis between pulmonary TB and other pulmonary non-TB conditions in past human skeletons. In individuals with pulmonary $\mathrm{TB}$ listed as cause of death, the upper and middle thoracic cage ribs are most frequently affected by new bone formation, and bilateral occurrence is more frequent. This study suggests that lamellar bone formation is more common on the vertebral end of the ribs in pulmonary TB, while in pulmonary non-TB diseases, woven bone is the most frequent type, affecting preferentially the sternal end of the inferior ribs. This location corresponds to inferior pulmonary segments where the majority of pulmonary non-TB infections take place (Cotran et al., 1999). Differences found between woven and lamellar bone frequencies by cause of death may be related to the acute or chronic nature of the diseases responsible. However, it is important to note that the distinction between types of new bone is not always a simple task, and more work on this subject is needed. Additional information can be obtained through radiographic analysis. Although expensive, this method permits clear evaluation of rib changes, particularly the relationship of "hair-on-end" lesions to neoplastic conditions.

Osteolytic lesions were more common than proliferative lesions in individuals with an extrapulmonary non-TB cause of death. Observations of the clavicles, sterna, and scapulae do not seem to be as relevant as rib observations for distinguishing between diseases. Further investigation on the etiology of proliferative lesions is necessary, especially on the ribs, in order to achieve a better understanding of pulmonary TB identification in past human populations, and consequently to aid in the knowledge of the origin and evolution of this disease.

\section{ACKNOWLEDGMENTS}

The authors thank the Museu Bocage (Museu Nacional de História Natural) in Lisbon, the Serviço de Radiologia dos Hospitais da Universidade de Coimbra, and the Departamento de Antropologia, Universidade de Coimbra. Special thanks go to Mary Lucas Powell and Hillary DelPrete who kindly edited our English-language usage. In addition, thanks go to the reviewers for their useful comments. This paper was presented at the 15th European Meeting of the Paleopathology Association, Durham, UK, in August 2004, with support from the Institute of Bioarchaeology (V.M.) and the Fundação Calouste Gulbenkian and the Centro de Investigação em Antropologia (A.L.S.).

\section{LITERATURE CITED}

Aiello L, Dean C. 1990. An introduction to human evolutionary anatomy. London: Academic Press.

Almeida AR. 1995. A tuberculose. Doença do passado, do presente e do futuro. Porto: Fundação Bial.

Antunes ML. 1995. Tuberculose em Portugal. Acta Med Port 8:559-565.

Asnis DS, Niegowska A. 1997. Tuberculosis of the rib. Clin Infect Dis 24:1018-1019.

Aufderheide A, Rodríguez-Martín C. 1998. The Cambridge encyclopedia of human paleopathology. Cambridge: Cambridge University Press.

Barrosa H. 1925. O conceito da tuberculose na medicina portuguesa. Porto: Emp. Ind. Gráf. do Porto.

Bass W. 1997. Human osteology: a laboratory and field manual. Columbia: Missouri Archaeological Society.

Brites G. 1912. Morgue de Coimbra: notas estatísticas. Mov Med 8:171-173.

Brown TS. 1980. Tuberculosis of the ribs. Clin Radiol 31:681-684.

Buckley H, Dias G. 2002. The distribution of skeletal lesions in treponemal disease: is the lymphatic system responsible? Int J Osteoarchaeol 12:178-188.

Buikstra J, Ubelaker D. 1994. Standards for data collection from human skeletal remains: proceedings of a seminar at the Field Museum of Natural History. Arkansas Archeological Survey research series 44. Fayetteville: Arkansas Archeological Survey.

Byers S, Roberts C. 2003. Bayes' theorem in paleopathological diagnosis. Am J Phys Anthropol 121:1-9.

Campillo D. 2001. Introducción a la paleopatología. Barcelona: Bellaterra.

Cardoso H. 2000. Dimorfismo sexual na estatura, dimensões e proporções dos ossos longos dos membros. O caso de uma amostra portuguesa dos séculos XIX-XX. Dissertação de mestrado em evolução humana. Coimbra: Universidade de Coimbra.

Cardoso H. In press. Contribution to the history of Portuguese physical anthropology: the Bocage Museum (National Museum of Natural History, Lisbon, Portugal) and its Identified Human Skeletal Collections. Lisbon: Publicações Avulsas do Museu Bocage. 
Carvalho AS. 1905. Acção do saneamento geral sobre a tuberculose. 3o Congresso Nacional contra a Tuberculose. Coimbra: Imprensa da Universidade.

Carvalho AS. 1907. I—quantos tuberculosos há no país? II—o erythema nodoso é uma tuberculide; assumptos dignos de estudo para os futuros congressos. IV Congresso da Liga Nacional contra a Tuberculose. Lisbon: Centro Typographico Colonial.

Carvalho FL. 1948. O diagnóstico em tisiologia. Jorn Med 11:173-186.

Castanheira AGC. 1919.Tuberculose pulmonar. Sua história e profilaxia. Dissertação de doutoramento. Coimbra: Universidade de Coimbra.

Chang DS, Rafii M, McGuinness G, Jagirdar J. 1998. Primary multifocal tuberculous osteomyelitis with involvement of the ribs. Skeletal Radiol 27:641-645.

Chang JH, Kim SK, Lee W. 1999. Diagnostic issues in tuberculosis of the ribs with a review of 12 surgically proven cases. Respirology 4:249-253.

Cotran R, Kumar V, Collins T. 1999. Robbins' pathologic basis of disease. London: W.B. Saunders Co.

Coutinho AC, editor. 1957. Dicionário enciclopédico de medicina. Lisbon: Argo Editora.

Currey JD. 2003. The many adaptations of bone. J Biomech $36: 1487-1495$.

Daniel T. 1997. Captain of death. The story of tuberculosis. Rochester, NY: University of Rochester Press.

Donoghue H, Ubelaker D, Spigelman M. 1999. The use of paleomicrobiological techniques in a current forensic case. In: Pálfi G, Dutour O, Deák J, Hutás I, editors. Tuberculosis: past and present. Budapest-Szeged: Golden Book/Tuberculosis Foundation. p 363-368.

Dudar JC. 1993. Identification of rib number and assessment of intercostal variation at the sternal rib end. J Forensic Sci 38:788-797.

Dunlap NE, Bass J, Fujiwara P, Hopewell P, Horsburgh CR, Salfinger M, Simone PM. 2000. Diagnostic standards and classification of tuberculosis in adults and children. Am J Respir Crit Care Med 161:1376-1395.

Eyler WR, Monsein LH, Beute GH, Tilley B, Schultz LR, Schmitt WG. 1996. Rib enlargement in patients with chronic pleural disease. Am J Radiol 167:921-926.

Gorski JP. 1998. Is all bone the same? Distinctive distributions and properties of non-collagenous matrix proteins in lamellar vs. woven bone imply the existence of different underlying osteogenic mechanisms. Crit Rev Oral Biol Med 9:201223 .

Guttentag AR, Salwen JK. 1999. Keep your eyes on the ribs: the spectrum of normal variants and diseases that involve ribs. Radiographics 19:1125-1142.

Hardy A. 1994. "Death is the cure of all disease": using the general register office cause of death statistics for 1837-1920. Soc Hist Med 7:473-492.

Harisinghani MG, McLoud TC, Shepard J-AO, Ko JP, Shroff MM, Mueller PR. 2000. Tuberculosis from head to toe. Radiographics 20:449-470.

Helms C. 1999. Radiología del esqueleto. Madrid: Marban.

Hoppa R, Saunders S. 1998. Two quantitative methods for rib seriation in human skeletal remains. J Forensic Sci 43:174177.

Ip M, Chen N-K, So S-Y, Chiu S-W, Lam W-K. 1989. Unusual rib destruction in pleuropulmonary tuberculosis. Chest 95:242-244.

Johnston WD. 1993. Tuberculosis. In: Kiple KF, editor: The Cambridge world history of human disease. Cambridge: Cambridge University Press. p 1059-1068.

Junqueira L, Carneiro J. 1999. Histologia básica 9a ed. Rio de Janeiro: Guanabara Koogan.

Kelley M, Micozzi M. 1984. Rib lesions in chronic pulmonary tuberculosis. Am J Phys Anthropol 65:381-386.

Lambert PM. 2002. Rib lesions in a prehistoric Puebloan sample from southwestern Colorado. Am J Phys Anthropol 117:281292.

Leader SA. 1950. Tuberculosis of the ribs. AJR 63:354-359.
Lee G, Im J-G, Kim JS, Kang HS, Han MC. 1993. Tuberculosis of the ribs: CT appearance. J Comput Assist Tomogr 17:363366.

Lewis M, Roberts C, Manchester K. 1995. Inflammatory bone changes in leprous skeletons from the medieval hospital of St. James and St. Mary Magdalene, Chichester, England. Int J Lepr Other Myobact Dis 63:77-85.

Mann R. 1993. A method for siding and sequencing human ribs. J Forensic Sci 38:151-155.

Marques AC, Matos V. 2002. Breast cancer and its palaeopathology. Four case studies from a Portuguese Human Skeletal Identified Collection (Lisbon, 20th century). Programabstracts from the 14th European Meeting of the Paleopathology Association, 28-31, August 2002, (Coimbra, Portugal). Coimbra: Departamento de Antropologia. p 97.

Mathlouthi A, M'Rad SB, Merai S, Friaa T, Mestiri L, Miled KB, Djenayah F. 1998. La tuberculose de la paroi thoracique. Rev Pneumol Clin 54:182-186.

Matos V. 2003. Incursões no trilho da tuberculose pulmonar. Diagnóstico diferencial com base no estudo da Colecção de Esqueletos Identificados do Museu Bocage, Lisboa. Dissertação de Mestrado em Evolução Humana. Coimbra: Universidade de Coimbra.

Molto JE. 1990. Differential diagnosis of rib lesions: a case study from middle Woodland Southern Ontario circa 230 A.D. Am J Phys Anthropol 83:439-447.

Moore K. 1995. Essential clinical anatomy. Baltimore: Williams \& Wilkins.

Nyman R, Brismar J, Hugosson C, Larsson S-G, Lundstedt C. 1996. Imaging of tuberculosis-experience from 503 patients. I. Tuberculosis of the chest. Acta Radiol 37:482-488.

Organização Mundial de Saúde. 1989. Classificação das doenças, traumatismos e causas de morte: 9a revisão-1975. Estatísticas da Saúde. Continente, Açores e Madeira. Lisboa: Instituto Nacional de Estatística. p 12-27.

Ortner D. 1992. Skeletal paleopathology. Probabilities, possibilities, and impossibilities. In: Verano J, Ubelaker D, editors. Disease and demography in the Americas. Washington, DC: Smithsonian Institution Press. p 5-13.

Ortner D. 2003. Identification of pathological conditions in human skeletal remains. San Diego: Academic Press.

Ortner D, Turner-Walker G. 2003. The biology of skeletal tissues. In: Ortner D, editor. Identification of pathological conditions in human skeletal remains. New York: Academic Press. p 11-35.

Pfeiffer S. 1991. Rib lesions and New World tuberculosis. Int J Osteoarchaeol 1:191-198.

Pinheiro J, Cunha E, Cordeiro C, Vieira DN. 2004. Bridging the gap between forensic anthropology and osteoarchaeology-a case of vascular pathology. Int J Osteoarchaeol 14: 137-144.

Pozniak A. 2001. Multidrug-resistant tuberculosis and HIV infection. Ann NY Acad Sci 953:192-198.

Resnick D. 1996a. Enostosis, hyperostosis, and periostitis. In: Resnick D, editor. Bone and joint imaging. London: W.B. Saunders Co. p 1211-1231.

Resnick D. 1996b. Skeletal metastases. In: Resnick D, editor. Bone and joint imaging. London: W.B. Saunders Co. p 1076-1091.

Roberts CA. 1999. Rib lesions and tuberculosis: the current state of play. In: Pálfi G, Dutour O, Deák J, Hutás I, editors. Tuberculosis: past and present. Budapest-Szeged: Golden Book Publisher and Tuberculosis Foundation. p 311-316.

Roberts CA. 2002. Tuberculosis in Britain: its history and palaeoepidemiology. Antropol Port 19:101-119.

Roberts CA, Buikstra JE. 2003. The bioarchaeology of tuberculosis: a global view on a reemerging disease. Gainesville: University Press of Florida.

Roberts CA, Manchester K. 1995. The archaeology of disease. 2nd ed. London: Sutton Publishing.

Roberts CA, Lucy D, Manchester K. 1994. Inflammatory lesions of ribs: an analysis of the Terry Collection. Am J Phys Anthropol 95:169-182.

Roberts CA, Boylston A, Buckley L, Chamberlain AC, Murphy EM. 1998. Rib lesions and tuberculosis: the paleopathological evidence. Tubercle Lung Dis 79:55-60. 
Santos AL. 1999. TB files: new hospital data (1910-1936) on the Coimbra Identified Skeletal Collection. In: Pálfi G, Dutour O, Deák J, Hutás I, editors. Tuberculosis: past and present. Budapest-Szeged: Golden Book Publisher and Tuberculosis Foundation. p 127-134.

Santos AL. 2000. A skeletal picture of tuberculosis: macroscopic, radiological, biomolecular, and historical evidence from the Coimbra Identified Skeletal Collection. Ph.D. dissertation on biological anthropology. Coimbra: Universidade de Coimbra.

Santos AL, Roberts C. 2001. A picture of tuberculosis in young Portuguese people in the early 20th century: a multidisciplinary study of the skeletal and historical evidence. Am J Phys Anthropol 115:38-49.

Santos AL, Roberts CA. In press. Anatomy of a serial killer: differential diagnosis of tuberculosis based on rib lesions of adult individuals from the Coimbra Identified Skeletal Collection, Portugal. Am J Phys Anthropol.

Schultz M. 2001. Paleohistopathology of bone: a new approach to the study of ancient diseases. Yrbk Phys Anthropol 44:106-147.

SPSS. 2001. SPSS for Windows. Release 11.0.0. Chicago: SPSS, Inc.

Su X, Sun K, Cui F, Landis W. 2003. Organization of apatite crystals in human woven bone. Bone 32:150-162.

Tatelman M, Drouillard E. 1953. Tuberculosis of the ribs. AJR 70:923-925.

Thillaud P. 1994. Lesions osteo-archeologiques: recueil et identification. Sceaux: Kronos B. Y.

Tobias P. 1991. On the scientific, medical, dental and educational value of collections of human skeletons. Int J Anthropol 6:277-280.
Ubelaker DH, Jones EB, Donoghue HD, Spigelman M. 2000. Skeletal and molecular evidence for tuberculosis in a forensic case. Anthropologie 38:193-200.

Videira W. 1991. A luta anti-tuberculose em Portugal—nota histórica. Bol Hosp Pulido Valente 4:253-259.

Wakely J, Manchester K, Roberts C. 1991. Scanning electron microscopy of rib lesions. Int J Osteoarchaeol 1:185-189.

Weiner S, Traub W, Wagner D. 1999. Lamellar bone: structurefunction relations. J Struct Biol 126:241-255.

White T. 2000. Human osteology. 2nd ed. San Diego: Academic Press.

Wood J, Milner G, Harpending H, Weiss K. 1992. The osteological paradox. Problems in inferring prehistoric health from skeletal samples. Curr Anthropol 33:343-370.

World Health Organization. 1994. TB, a global emergency. Geneva: World Health Organization.

World Health Organization. 2004a. Tuberculosis (fact sheet no. 104) [online]. Geneva: World Health Organization [accessed September 21, 2004]. Available on URL: http://www.who.int/ mediacentre/factsheets/fs104/en/

World Health Organization. 2004b. Global tuberculosis control: surveillance, planning, financing. Geneva: World Health Organization.

Wright LE, Yoder CJ. 2003. Recent progress in bioarchaeology: approaches to the osteological paradox. J Archaeol Res 11:4370 .

Yoshikawa H, Shimizu K, Nakase T, Takaoka K. 1994. Periosteal sunburst spiculation in osteosarcoma. Clin Orthop 308: 213-219. 